\title{
PRIVATE ATTORNEYS GENERAL, PREVAILING PARTIES, AND PUBLIC BENEFIT: ATTORNEY'S FEES AWARDS FOR CIVIL RIGHTS PLAINTIFFS
}

\author{
DAVID SHUB
}

\section{INTRODUCTION}

Without an attorney's aid, the victim of civil rights violations will most likely gain no relief. Consider the following hypothetical:

Joe, a homeless man eager to improve his lot, seeks to supplement his high school education by taking advantage of the resources of the public library located three blocks from the back alley where he often spends his nights. The library, upon receiving complaints from library patrons who claim to be disturbed by Joe's presence, expels Joe and bars him from reentering the hibrary on the grounds that only those who can supply the library with a home address are permitted to use the library's facilities. In fact, the library enforces this policy only against black wouldbe patrons; Joe's expulsion resulted not from his creating a disturbance, but from his being black. Joe brings suit under 42 U.S.C. $\& 1983$, alleging the denial of his equal protection rights, seeking both injunctive and monetary relief. Joe cannot afford to pay for legal services; yet an attorney is willing to take Joe's case because of the award of attorney's fees he knows will be forthcoming if Joe's suit is successful.

While the suit is pending, Joe gets a job and earns enough to rent an apartment. Upon supplying the library with his new home address, Joe gains access to the library; he must drop his claim for injunctive relief. The jury later determines that although Joe was denied equal protection, he suffered no compensable harm. Accordingly, the trial judge enters judgment on Joe's behalf, awarding him nominal damages. Joe then brings an action under 42 U.S.C. \& 1988, seeking an award of attorney's fees incurred in the litigation of his civil rights suit.

In a 1976 Senate Report, ${ }^{1}$ the Senate Committee on the Judiciary

1. S. REP. No. 1011, 94th Cong., 2d Sess. (1976), reprinted in 1976 U.S.C.C.A.N. 
recognized the importance of awarding attorney's fees to civil rights plaintiffs like Joe, who cannot afford legal representation, yet have valid civil rights claims, the enforcement of which is in the public interest. ${ }^{2}$ To encourage such plaintiffs to bring actions to enforce their rights, Congress enacted the Civil Rights Attorney's Fees Act of $1976,{ }^{3}$ amending 42 U.S.C. $\S 1988$. With respect to the awarding of attorney's fees, section 1988 now provides:

In any action or proceeding to enforce a provision of sections 1981, 1982, 1983, 1985, and 1986 of this title, title IX of Public Law 92-318 [20 U.S.C. $\S \S 1681-1688$ ], or title VI of the Civil Rights Act of 1964 [42 U.S.C. $\$ \S 2000 d-2000 d-4$ ], the court, in its discretion, may allow the prevailing party, other than the United States, a reasonable attorney's fee as part of the costs. ${ }^{4}$

Regrettably, the term "prevailing party" is, without proper context, ambiguous. As such, Justice Scalia's assertion that "[r]espect for ordinary language requires that a plaintiff receive at least some relief on the merits of his claim before he can be said to prevail"s is difficult to accept. Without further guidance, ordinary language could just as easily require merely that a plaintiff have an issue resolved in his favor before he can be said to "prevail."

Because of the ambiguity, understanding what class of parties Congress intended to reward with attorney's fees requires an awareness of the proper context for the term "prevailing party"-i.e., the legal climate in which Congress passed the Civil Rights Attorney's Fees Act and the legislative history of the Act. Unfortunately, the Supreme Court has for the most part ignored these crucial interpretative aids. Consequently, the Court has stifled Congress's aspiration to provide citizens with the ability to vindicate their rights where such vindications help to secure the rights of all.

Part I of this Note examines the circumstances leading to the passage of the Civil Rights Attorney's Fees Act of 1976 and the legislative history of the Act. This examination reveals that in order to carry out the congressional policy inherent in the Act of

5908.

2. See id. at 2, reprinted in 1976 U.S.C.C.A.N. at 5910.

3. Pub. L. No. 94-559, § 2, 90 Stat. 2641.

4. 42 U.S.C. $\S 1988$ (1988).

5. Hewitt v. Helms, 482 U.S. 755, 760 (1987). 
encouraging the public-benefitting private enforcement of civil rights laws, courts should consider the public benefit, if any, generated by a civil rights plaintiff's suit in determining whether and to what extent the plaintiff "prevailed."

Part II charts the evolution of the Supreme Court's treatment of the Act, examining City of Riverside v. Rivera, ${ }^{6}$ Hewitt $v$. Helms, ${ }^{7}$ Rhodes v. Stewart, ${ }^{8}$ and Farrar v. Hobby. ${ }^{9}$ Currently, a civil rights plaintiff is not held to have "prevailed" unless he has reaped some private benefit as a result of having brought his civil rights suit; no weight is given to any public benefit a plaintiff's suit may have engendered.

Part III argues for a reformulation of the "prevailing party" test. Under the Court's current interpretation of the Act's "prevailing party" language, Joe would not receive an award of attorney's fees. The Court should adopt a new test that considers whether a plaintiff's civil rights suit has generated any public benefit, both when determining whether the plaintiff "prevailed" and when analyzing the extent to which the plaintiff has "prevailed." Under such a test, Joe and other "private attorneys general" who successfully vindicate their rights in court would qualify as "prevailing parties.".

\section{The Legislative Intent: "Private Attorneys General"}

An examination of the circumstances leading to the adoption of the Civil Rights Attorney's Fees Act of 1976 and of the legislative history of the Act reveals that one of the basic principles underlying the adoption of the Act is that civil rights plaintiffs are relied upon to act as "private attorneys general" in the prosecution of civil rights violations. The significance of the common

6. 477 U.S. 561 (1986).

7. 482 U.S. 755 (1987).

8. 488 U.S. 1 (1988).

9. 113 S. Ct. 566 (1992).

10. The notion of a "private attorney general" was first recognized by Judge Jerome Frank in Associated Industries of New York State v. Ickes, 134 F.2d 694 (2d Cir. 1943). Judge Frank wrote that

[i]nstead of designating the Attorney General, or some other public officer, to bring [an action], Congress can constitutionally enact a statute conferring on any non-official persons, or on a designated group of non-official persons, authority to bring a suit ... even if the sole purpose is to vindicate the public interest. Such persons, so authorized, are, so to speak, private Attorney Generals.

Id. at 704 (footnote omitted). 
reference to civil rights plaintiffs as "private attorneys general" in the House and Senate Reports ${ }^{11}$ on the Act is underscored by the Supreme Court's holding in Alyeska Pipeline Service Co. v. Wilderness Society ${ }^{12}$ that courts may not, without congressional authorization, award attorney's fees to plaintiffs based on a common law "private attorney general" theory. ${ }^{13}$

\section{A. The Circumstances of the Act's Adoption: Alyeska's Rejection} of the Common Law "Private Attorney General" Doctrine

In Alyeska, the Supreme Court refused to recognize a "private attorney general" exception to the "American Rule," which requires each party in a civil action to bear its own attorney's fees. The Court would not countenance the D.C. Circuit's recognition that

[t] the violation of an important public policy may involve little by way of actual damages, so far as a single individual is concerned, or little in comparison with the cost of vindication .... In such instances public policy may suggest an award of costs that will remove the burden from the shoulders of the plaintiff seeking to vindicate the public right. ${ }^{25}$

Rather, it explained that insofar as the courts operate under the "American Rule" "the circumstances under which attorney's fees are to be awarded and the range of discretion of the courts in making those awards are matters for Congress to determine."16

11. See H.R. REP. No. 1558, 94th Cong., 2d Sess. 8-9 (1976); S. REP. No. 1011, supra note 1, at 2, reprinted in 1976 U.S.C.C.A.N. at 5910.

12. 421 U.S. 240 (1975).

13. Id. at 262.

14. Id. at 247. The Alyeska Court first focused on the difference between the "American Rule" and the common British practice of having the defeated litigant pay both hitigants' attorney's fees. Id. Neither British nor American common law allows the awarding of attorney's fees; it is only pursuant to broad legislative authorization that the "British Rule" provides for the awarding of attorney's fees. See id.

15. Wilderness Soc'y v. Morton, 495 F.2d 1026, 1030 (D.C. Cir. 1974) (quoting Knight v. Auciello, 453 F.2d 852, 853 (1st Cir. 1972)). The plaintiff had obtained an injunction against a defendant who purportedly intended to issue a certain right-of-way and certain land use permits in violation of section 28 of the Mineral Leasing Act of 1920. Alyeska, 421 U.S. at 242 (citing Mineral Leasing Act of 1920, § 28, 41 Stat. 449 (codified as amended at 30 U.S.C. $\S 185$ (1988))).

16. Alyeska, 421 U.S. at 262. 
With this explanation, the Court, asking for "legislative guidance,"17 invited Congress to instruct the courts as to which fee-shifting policies Congress wished the courts to enforce. The Court did not order Congress to dispose of the common law "private attorney general" theory in providing for the availability of attorney's fees awards; rather, the Court requested Congress to provide a limited domain in which the courts could apply the theory. ${ }^{18}$

B. The House and Senate Reports on the. Civil Rights Attorney's Fees Act of 1976: Guides to the Proper Interpretation of the "Prevailing Party" Language

With the Civil Rights Attorney's Fees Act of 1976, Congress accepted the Court's invitation to instruct the courts with regard to the awarding of attorney's fees. In amending 42 U.S.C. $\S 1988$, Congress authorized courts to award attorney's fees to parties who "prevail" in suits brought under any of several specified sections of the United States Code. ${ }^{19}$

1. 42 U.S.C. \& 1988 Plaintiffs as "Private Attorneys General." The legislative history clearly indicates that the Civil Rights Attorney's Fees Act of 1976 was passed to counteract the limiting effects of the Supreme Court's holding in Alyeska that the courts do not have the authority to invoke a "private attorney general" exception to the "American Rule" without specific legislative guidance. ${ }^{20}$ Congress amended 42 U.S.C. $\S 1988$ to revive the

17. Id. at $263-64$.

18. Id. In noting that Congress has the authority to mandate a scheme of awarding attorney's fees resembling the common British practice, see id. at 262, the Alyeska Court was consistent with prior judicial practice. When U.S. courts have found a legislative intent to mandate the awarding of attorney's fees to the victorious party, they have dutifully enforced the scheme. See, e.g., Hall v. Cole, 412 U.S. 1, 9-14 (1973) (awarding attorney's fees pursuant to the Labor-Management Reporting and Disclosure Act, \& 102, 29 U.S.C. \& 412 (1988)); Arabian Am. Oil Co. v. Scarfone, 939 F.2d 1472 (11th Cir. 1991) (awarding attorney's fees pursuant to the Organized Crime Control Act of 1970, 18 U.S.C. \& 1964(c) (1988)); Cazalas v. Departınent of Justice, 709 F.2d 1051 (5th Cir. 1983) (awarding attorney's fees pursuant to the Freedom of Information Act, 5 U.S.C. $\S 552(\mathrm{a})(4)(\mathrm{E})(1988))$.

19. See supra text accompanying note 4.

20. See, e.g., S. REP. NO. 1011, supra note 1, at 1, reprinted in 1976 U.S.C.C.A.N. at 5909 (stating that "[t]he purpose of this amendment is to remedy anomalous gaps in our civil rights laws created by the United States Supreme Court's recent decision in Alyeska Pipeline Service Co. v. Wilderness Society"). 
"private attorney general" doctrine; the House and Senate Reports each noted the need for private enforcement of the civil rights laws to which section 1988 pertains. ${ }^{21}$

Congress's characterization of civil rights plaintiffs as "private attorneys general" indicates its recognition that the enforcement of an individual's civil rights at the expense of the rights violator deters further civil rights violations. ${ }^{2}$ The general public certainly is able to benefit from an action even if the individual bringing the action is unable personally to benefit. In amending section 1988, Congress focused not on the benefits received by individual plaintiffs in civil rights cases, but on the benefits generated for the public by plaintiffs who would not have brought cases without the relief provided for by section $1988 .^{23}$ It follows, then, that any such plaintiff may "prevail" by encouraging a public benefit, even if the plaintiff's only private relief is for the plaintiff qua a member of society.

2. Qualifying the Level of Success Required to Attain "Prevailing Party" Status: Vindication of Rights. The success of a lawsuit can be measured in various ways. A plaintiff might be said to have "succeeded" if: 1) he has received precisely the relief he requested; 2) he has received any tangible or equitable relief at all; or 3) he merely has had his rights vindicated by virtue of the court's holding in his favor, regardless of the nature of any relief which might accompany such a vindication.

An examination of the legislative history of the Civil Rights Attorney's Fees Act of 1976 reveals that the third category of success-a mere "vindication of rights"-is sufficient to earn a civil

21. See H.R. REP. NO. 1558, supra note 11, at 1 ("The effective enforcement of Federal civil rights statutes depends largely on the efforts of private citizens."); S. REP. No. 1011, supra note 1, at 2, reprinted in 1976 U.S.C.C.A.N. at 5910 ("All of these civil rights laws depend heavily upon private enforcement, and fee awards have proved an essential remedy if private citizens are to have a meaningful opportunity to vindicate the important Congressional policies which these laws contain.").

22. See H.R. REP. No. 1558, supra note 11, at 2 (referring with approval to courts that "prior to Alyeska ... had allowed fees on the theory that civil rights plaintiffs act as 'private attorneys general' in eliminating discriminatory practices adversely affecting all citizens"); S. REP. No. 1011, supra note 1, at 2, reprinted in 1976 U.S.C.C.A.N. at 5910 (expressing the importance of having civil rights plaintiffs vindicate their rights so that "those who violate the Nation's fundamental laws [do not] proceed with impunity").

23. See H.R. REP. NO. 1558, supra note 11, passim; S. REP. No. 1011, supra note 1, passim. 
rights plaintiff "prevailing party" status. The Senate Report ex-plained that "[i]f private citizens are to be able to assert their civil rights, and if those who violate the Nation's fundamental laws are not to proceed with impunity, then citizens must have the opportunity to recover what it costs them to vindicate these rights in court." Similarly, the House Report indicated that a plaintiff need not obtain relief on the merits of his case before he is a "prevailing party" within the meaning of the Act. It recognized that "in some cases, immunity doctrines and special defenses, available only to public officials, preclude or severely limit the damage remedy. Consequently[,] awarding counsel fees to prevailing plaintiffs in such litigation is particularly important and necessary if Federal civil and constitutional rights are to be adequately protected."25 Congress mandated that a civil rights plaintiff may be said to have "prevailed" despite having failed to obtain any relief on the merits of his action if he has obtained a legal pronouncement that his rights were violated. This least onerous means of qualifying as a "prevailing party"-i.e., achieving merely a vindication of rights--is wholly consistent with the "private attorney general" theory underlying the Act: A vindication of a plaintiff's rights coupled with an award of attorney's fees informs those who might violate the civil rights of any citizen that their unlawful conduct will be prosecuted at their own expense, thereby providing the public benefit of deterring such unlawful conduct.

\section{The Court's Doctrine: Private Relief}

The lower federal courts have struggled with the notion of "prevailing parties"; $;$ on occasion, the Supreme Court has provid-

24. S. REP. No. 1011, supra note 1, at 2, reprinted in 1976 U.S.C.C.A.N. at 5910 (emphasis added).

25. H.R. REP. No. 1558, supra note 11 , at 9 (citations omitted); see also id. at 8 (" $[T]$ he word 'prevailing' is not intended to require the entry of a final order before fees may be recovered .... '[T] $\mathrm{T}$ he entry of any order that determines substantial rights of the parties may be an appropriate occasion upon which to consider the propriety of an award of counsel fees....'") (quoting Bradley v. Richmond Sch. Bd., 416 U.S. 696, 722 n.28 (1974)).

26. See, e.g., Ruggiero v. Krzeminski, 928 F.2d 558, 564 (2d Cir. 1991) (holding that a plaintiff who is awarded nominal damages "prevails"); Simien v. City of San Antonio, 809 F.2d 255, 258 (5th Cir. 1987) (requiring that a party succeed on the "central issue" and receive the primary relief sought in order to "prevail" within the meaning of 42 U.S.C. § 1988); Gingras v. Lloyd, 740 F.2d 210, 212 (2d Cir. 1984) (requiring that a party succeed on any significant issue and receive some of the benefits he sought in order to 
ed some direction. ${ }^{27}$ However, in providing that direction, the Court has ignored the "private attorney general" intent behind the Civil Rights Attorney's Fees Act of 1976. As a result of this disregard, the Court has adopted a faulty standard for determining when a civil rights plaintiff is eligible for an award of attorney's fees, focusing only on the private relief which a plaintiff obtains.

City of Riverside $v$. Rivera, ${ }^{28}$ a comparatively early case, survives as something of an anomaly. In Rivera, the Supreme Court, in upholding an award of attorney's fees more than seven times greater than the compensatory and punitive damages award in the underlying civil rights suit, ${ }^{29}$ provided an examination of the Act's legislative history since unencountered in the Court's opinions, be they majority opinions, concurrences, or dissents.

Since Rivera, the Court has not rejected the analysis of the legislative history presented by the Rivera plurality-it has simply ignored it. In two notable cases, the Court, ignoring the Act's legislative history, established and then expanded its misinterpretation of the Act's "prevailing party" language. In Hewitt $v$. Helms, ${ }^{30}$ the Court held that a civil rights plaintiff must achieve some significant private relief before qualifying for a section 1988 attorney's fees award. In Rhodes $v$. Stewart, ${ }^{31}$ the Court established further that a declaratory judgment in a civil rights plaintiff's favor is not sufficient to qualify that plaintiff for an attorney's fees award unless it is actually taken advantage of by that plaintiff.

Most recently, in Farrar v. Hobby, ${ }^{32}$ the Court further confounded the congressional intent behind the Act by ostensibly declaring a plaintiff to be a "prevailing party" after being awarded nominal damages, but then summarily denying that the plaintiff

\footnotetext{
"prevail").

27. See, e.g., Farrar v. Hobby, 113 S. Ct. 566 (1992) (holding that a nominal damages award is sufficient to qualify a plaintiff as a "prevailing party"); Texas State Teachers Ass'n v. Garland Indep. Sch. Dist., 489 U.S. 782 (1989) (holding that a party need only succeed on some "significant issue" to "prevail"); Rhodes v. Stewart, 488 U.S. 1 (1988) (per curiam) (holding that a declaratory judgment, absent private relief, is insufficient to qualify a plaintiff as a "prevailing party"); Hewitt v. Helms, 482 U.S. 755 (1987) (holding that a plaintiff must obtain private relief to "prevail").
}

28. 477 U.S. 561 (1986).

29. Id. at 564-65 (plurality opinion).

30. 482 U.S. 755 (1987).

31. 488 U.S. 1 (1988).

32. 113 S. Ct. 566 (1992). 
might be entitled to attorney's fees. The Court based its holding on the seemingly irrelevant point that the tangible relief obtained was minuscule compared to the damages prayed for by the plaintiff. Furthermore, although admitting that a "private attorney general" theory underlies the Act, Justice O'Connor, in a fifth-vote concurrence, refused to allow the district court that originally awarded the attorney's fees an opportunity to articulate a public benefit basis for its award and refused also to recognize the plaintiffs' vindication of their constitutional rights as a potential substantial public benefit.

\section{A. City of Riverside v. Rivera}

In City of Riverside v. Rivera, ${ }^{33}$ the Court considered not whether attorney's fees should be awarded at all, but what factors may be taken into consideration in determining the appropriate fee award once it has been determined that some award is appropriate. In Rivera, civil rights plaintiffs had been awarded $\$ 33,350$ in compensatory and punitive damages. ${ }^{34}$ The issue before the Court was whether a subsequent award of $\$ 245,456.25$ in attorney's fees was reasonably proportionate to the degree of the plaintiffs' "success" in the underlying suit. ${ }^{35}$

The Rivera Court insisted that the degree of a civil rights plaintiff's "success" cannot be determined simply by measuring the amount of damages received by the plaintiff. Rather, "[r]egardless of the form of relief he actually obtains, a successful civil rights plaintiff often secures important social benefits that are not reflected in nominal or relatively small damages awards.."36 Declaring that "[a] rule that limits attorney's fees in civil rights cases to a proportion of the damages awarded would seriously undermine Congress" purpose in enacting $\S 1988, " 37$ the Court held that a plaintiff's "success," for section 1988 purposes, is a function not just of the amount of relief that the plaintiff obtained for himself in the underlying suit, but also of the nature of the benefits that accrue to the public as a result of the plaintiff's suit. Indeed, the Rivera plurality explicitly recognized that a plaintiff who obtains

\footnotetext{
33. 477 U.S. 561 (1986).

34. Id. at 564-65 (plurality opinion).

35. See id. at 565-67.

36. Id. at 574 .

37. Id. at 576.
} 
relief in a civil rights lawsuit "does so not for himself alone but also as a 'private attorney general,' vindicating a policy that Congress considered of the highest importance." ${ }^{38}$

\section{B. Hewitt v. Helins}

Only a year after the Rivera decision, the Court began on its course of wholly disregarding the Act's legislative history. In Hewitt $v$. Helms, ${ }^{39}$ the Court, faced with the Act's facially ambiguous language, invented its own definition of "prevailing party." Since Hewitt, the Court has continued to pile misinterpretation upon misinterpretation.

Hewitt arose froin the alleged denial of Aaron Helins's due process rights. A prison riot had occurred while Helms was an inmate at the Pennsylvania State Correctional Institution at Huntington. A prison hearing coinmittee, relying solely on the testimony of a correctional officer's recollection of an undisclosed informant's statements, found Helms guilty of misconduct for striking an officer during the riot. Pursuant to the finding of guilt, Helins was sentenced to six months' disciplinary restrictive confinement. Helms brought suit under 42 U.S.C. $\S 1983$ against various prison officials for violating his due process rights: first, in failing to provide him with a prompt hearing on his misconduct charge; and second, in basing his guilt solely on uncorroborated hearsay testimony. ${ }^{40}$

The district court rendered summary judgment against Helms several months after his release from prison. ${ }^{41}$ The court of appeals reversed, finding, in particular, that the conviction of Helms on the misconduct charge was based on hearsay evidence, and that Helms had therefore been denied due process. ${ }^{42}$ The court of appeals instructed the district court to enter summary judgment for Helms on this second due process claim if an immunity defense could not be established. ${ }^{43}$

38. Id. at 575 (quoting H.R. REP. No. 1558, supra note 11, at 2 (quoting Newman v. Piggie Park Enters., 390 U.S. 400, 402 (1968))).

39. 482 U.S. 755 (1987).

40. Id. at 757 .

41. Id.

42. Id. at 758.

43. Id. 
On remand, Helms sought only to recover monetary damages. The district court denied Helms any remedy, granting summary judgment to the defendants on the basis of their qualified immunity. ${ }^{44}$ On appeal, Helms sought both monetary damages and equitable relief in the form of expunction of his misconduct conviction from his record. ${ }^{45}$ While this appeal was pending, the Pennsylvania Bureau of Corrections adopted regulations governing the use of information from confidential sources in inmate disciplinary proceedings. ${ }^{45}$ The court of appeals then affirmed the district court's decision.

After that defeat, Helms sought to recover attorney's fees under section 1988 in the district court. The district court rejected Helms's claim, denying Helms any compensatory damages remedy because of the defendants' qualified immunity, and denying Helms's request for the equitable relief of having the misconduct conviction expunged because his having been released from prison made this request moot. ${ }^{47}$ The Third Circuit reversed, finding Helms to be a "prevailing party" because its "prior holding that Helms's constitutional rights were violated was 'a form of judicial relief which serve[d] to affirm the plaintiff's assertion that the defendants' actions [had been] unconstitutional and which [would] serve as a standard of conduct to guide prison officials in the future." "48 Furthermore, the Third Circuit directed the district court to consider whether Helms's suit had been a "catalyst" for the Pennsylvania Bureau of Corrections' revision of its regulations governing inmate disciplinary hearings, and if so, to reconsider whether Helms's suit's "catalyst" status entitled Helms to attorney's fees. ${ }^{49}$

The Third Circuit's decision-to remand to the district court to consider whether either its pronouncement that Helms's constitutional rights had been violated or Helms's suit's potential "catalyst" status qualified Helms for an award of attorney's fees-was reversed by the Supreme Court. After observing that a plaintiff must "receive at least some relief on the merits of his claim before
44. Id.
45. Id.
46. Id. at 759.
47. Id.
48. Id. (quoting Helıns v. Hewitt, 780 F.2d 367, 370 (3d Cir. 1986)).
49. Id. 
he can be said to prevail,"s0 the Court asserted that "Helms obtained no relief .... No injunction or declaratory judgment was entered in his favor. Nor did Helms obtain relief without benefit of a formal judgment-for example, through a consent decree or settlement." ${ }^{\text {11 }}$ Helms argued that the Third Circuit's prior holding that the disciplinary proceeding was unconstitutional had constituted a "vindication of rights," party" under section 1988. The Court rejected this argument, asserting that a judicial pronouncement constitutes relief on the merits only if it settles "some dispute which affects the behavior of the defendant towards the plaintiff." H3 Helms's "vindication of rights" argument failed because the vindication of Helms's rights had had no effect on the behavior of the prison officials towards Helms.

Similarly, the Court dismissed Helms's "catalyst" argument. In rejecting the argument, the Court did not invoke standards establishing a threshold type of benefit or a threshold degree of causality between a suit and some benefit. Instead, the Court based its holding that Helms was not entitled to "prevailing party" status under a "catalyst" theory on its assertion that by the time the Pennsylvania Bureau of Corrections had amended its regulations, Helms had been released from prison and therefore "[had] not and could not [have gotten] redress from promulgation of the informant-testimony regulations." ${ }^{.54}$ The Court held that since Helms had not benefitted from the promulgation of the new regulations, he could not be considered to have "prevailed."ss

In insisting that Helms would have had to benefit personally from his suit's outcome before he could qualify as a "prevailing party," the Court failed to value, or even to consider, the immediate effect which the adoption of the new regulations had had on every other inmate in a Pennsylvania prison. The Court paid no heed to Congress's classification of civil rights plaintiffs as "private attorneys general" and consequently misinterpreted section 1988's "prevailing party" language as making private benefit a prerequisite to attorney's fees awards.

50. Id. at 760 .

51. Id.

52. Id. at 761 (citation omitted).

53. Id. As noted above, the Court held that a plaintiff must "receive at least some relief on the merits" to qualify as a "prevailing party."

54. Id. at 763 .

55. Id. 
C. Rhodes v. Stewart

The following year, the Court further limited the class of plaintiffs that may qualify as "prevailing parties." In Rhodes $v$. Stewart, ${ }^{56}$ the Court held that even if a court awards a civil rights plaintiff equitable relief, that plaintiff is not a "prevailing party" unless he actually takes advantage of the equitable relief.

Rhodes arose out of a complaint filed by Ohio Department of Rehabilitation and Correction inmates Albert Reese and Larry Stewart under 42 U.S.C. $\S 1983$, who alleged First and Fourteenth Amendment violations by prison officials who had denied them permission to subscribe to a magazine. ${ }^{57}$ The district court ruled that the officials had failed to provide Reese and Stewart procedural and substantive due process in denying their requests, and ordered the officials to comply with proper procedural and substantive standards; but it did not issue its opinion and accompanying order until after Reese had died and Stewart had been released from custody. ${ }^{58}$ Two months after issuing its opinion and accompanying order, the district court awarded attorney's fees to Reese and Stewart. ${ }^{59}$ The Sixth Circuit upheld the award of attorney's fees, noting that unlike the plaintiff in Hewitt, Reese and Stewart had received declaratory relief. ${ }^{60}$

The Supreme Court found the Sixth Circuit's characterization of the district court's ruling as a declaratory judgment to be inapposite. The Court asserted that a declaratory judgment, like any other judgment, "will constitute relief, for purposes of $\S 1988$, if, and only if, it affects the behavior of the defendant toward the plaintiff." district court issued its order, they had not had the opportunity to enjoy the improved treatment mandated by the district court.

With Rhodes, the Court established that a civil rights plaintiff needs not only to have been granted a judicial remedy, but also to have taken advantage of that remedy, before he qualifies as a "prevailing party." In making the point that no party had benefitted from the litigation, the Rhodes Court carefully noted that

\footnotetext{
56. 488 U.S. 1 (1988) (per curiam).

57. Id. at 2 .

58. Id. at $2-3$.

59. Id. at 2 .

60. Id. at 3.

61. Id. at 4.
} 
"[t]he lawsuit [had] not [been] brought as a class action, but by two plaintiffs." ${ }^{\text {"62 }}$ As in Hewitt, the Court fully examined the effect of the litigation on the parties to the litigation, but failed to consider the effect of the litigation on the rest of society: Although the defendant officials had not been able to change their behavior towards the plaintiffs, they had had to apply procedural and substantive standards articulated by the district court in treating the similar requests of other prisoners. Because the parties bringing the action had reaped no immediate private benefit, the Court found it inappropriate to award attorney's fees to those parties-despite the substantial immediate public effect of the suit's outcome on the prison officials' behavior.

\section{Farrar v. Hobby}

In Farrar v. Hobby, ${ }^{63}$ the Court held tightly to the fabricated distinction of whether a suit's judgment "modifies the defendant's behavior for the plaintiff's benefit ...."64 And although in her concurrence-the fifth vote in a 5-4 decision-Justice O'Connor went beyond Hewitt and Rhodes by recognizing that a "private attorney general" theory underlies the Civil Rights Attorney's Fees Act of $1976,{ }^{65}$ she firmly refused to accept the consequences of this recognition.

Farrar arose out of a suit brought under 42 U.S.C. $\S 1983$ and 42 U.S.C. $\S 1985$ by Joseph Farrar against then-Lieutenant Governor of Texas William Hobby, among others. ${ }^{66}$ In the suit, Farrar alleged that the defendants had violated his civil rights in depriving him of his liberty and property without due process of law through malicious prosecution aimed at closing the school he owned and operated. ${ }^{67}$ Originally, Farrar sought injunctive relief and monetary damages; through amendments to the complaint he

62. Id.

63. 113 S. Ct. 566 (1992).

64. Id. at 574.

65. Id. at 578 (O'Connor, J., concurring).

66. Id. at $\mathbf{5 7 0 .}$

67. Id. Farrar operated Artesia Hall, a facility for troubled teenagers in Liberty County, Texas. He was indicted for the murder of one of his students in 1973, for willfully failing to provide her with inedical treatment and failing to hospitalize her in a timely fashion. Shortly thereafter, the state of Texas obtained a temporary injunction closing Artesia Hall. Id. 
dropped, among other things, the claim for injunctive relief. ${ }^{6 s}$ The jury found that Hobby had illegally deprived Farrar of a constitutional right, but that the deprivation had not been the proximate cause of any injury. ${ }^{69}$ Accordingly, the district court ordered the case dismissed on the merits with no award of any kind..$^{70}$ On remand, the Farrars ${ }^{31}$ were awarded nominal damages; they then filed an application for attorney's fees under section $1988 .{ }^{n}$ The district court entered an award of over $\$ 300,000$, for attorney's fees and expenses, in favor of the Farrars. ${ }^{73}$ The Fifth Circuit reversed, holding that an award of nominal damages did not meaningfully "change the legal relationship" between the defendant and the plaintiff. ${ }^{24}$

The Supreme Court, citing, inter alia, Hewitt and Rhodes, found that nominal damages are sufficient to qualify a plaintiff as a prevailing party, insofar as "[a] judgment for damages in any amount, whether compensatory or nominal, modifies the defendant's behavior for the plaintiff's benefit by forcing the defendant to pay an amount of money he otherwise would not pay."75 Nevertheless, the Court affirmed the Fifth Circuit, basing its decision on the assertion that the Farrars "received nominal damages instead of the $\$ 17$ million in compensatory damages that they sought"76 and the conclusion that "[t]his litigation accomplished little beyond giving petitioners 'the moral satisfaction of knowing that a federal court concluded that [their] rights had been violated' in some unspecified way."

Unlike any opinion in Hewitt and Rhodes, Justice O'Connor's concurrence in Farrar referenced the "private attorney general" theory underlying the Civil Rights Attorney's Fees Act of 1976. Justice O'Connor even went as far as to term the Act "a tool that ensures the vindication of important rights." ${ }^{.78}$ However, she

68. Id.

69. Id.

70. Id.

71. Before the case was tried to a jury, Farrar died, and Pat Smith and Dale Farrar, co-administrators of Farrar's estate, were substituted as plaintiffs. Id.

72. Id.

73. $I d$.

74. Id. at 571.

75. Id. at 574 .

76. Id.

77. Id. (quoting Hewitt v. Helms, 482 U.S. 755, 762 (1987)) (alteration in original).

78. Id. at 578 (O'Connor, J., concurring). 
quickly dismissed the notion that the Act might be such a tool in the instant case, claiming that "one searches these facts in vain for the public purpose this litigation might have served."? Justice O'Connor's determinative fifth vote rested on her refusal to acknowledge the public value engendered by the vindication of Farrar's rights.

\section{THE COURT's Mistakes: IgNORING THE "PRIVATE ATTORNEY GENERAL" DOCTRINE AND UNDERVALUING THE VINDICATION OF RIGHTS}

To the detriment of the enforcement of our civil rights, the Court has abandoned Rivera's accurate evaluation of the legislative intent when determining whether and to what extent civil rights plaintiffs are "prevailing parties." Civil rights plaintiffs should be held to have "prevailed" whenever their litigation encourages a public benefit. Litigation encourages a public benefit when it results in changed law or governmental policy that mandates greater respect for citizens' civil rights; it also creates a public benefit whenever it results in a vindication of rights at the expense of a rights violator and thereby deters future violations of rights. ${ }^{80}$ If

79. II.

80. Perhaps Congress thought that the mere pronouncement of a violation of civil rights would deter future violations of the same ilk because of the sheer compelling force of judicial edicts. Or perhaps Congress's intent to encourage civil rights plaintiffs was based on a behief that the public's increased awareness of the defendant's wrongdoing would precipitate a change through the political process which would deter the defendant from repeating such violations. For some reason, Congress valued the public service performed by a plaintiff who, through a court's legal pronouncement, demonstrated that a defendant's bad acts constituted a violation of the plaimtiff's civil rights. In the estimation of the Congress that passed the Act, a public benefit sufficient to qualify a ("private attorney general") plaintiff as a "prevailing party" results whenever a court vindicates the plaintiff's rights.

Furthermore, although a legal pronouncement that a plaintiff's civil or constitutional rights have been violated is sufficient-under the interpretation of the "prevailing party" requirement proposed here-to qualify the plaintiff as a "prevailing party," such a pronouncement is not necessary-even under the Court's current interpretation-to so qualify the plaintiff. "Voluntary" action taken by a defendant that confers some benefit on society qualifies a "private attorney general" plaintiff as a "prevailing party" just as surely as a settlement that confers some benefit on the plaintiff qualifies the plaintiff as a "prevailing party." See Maher v. Gagne, 448 U.S. 122, 129 (1980).

It is interesting to note that if the Court heard a case involving the violation of an individual's civil or constitutional rights in which the resolution were identical to that of Alyeska's underlying suit, and if the Court applied its interpretation of the Act's "prevailing party" language, the plaintiff would still be demied attorney's fees. Although such 
the Court were to extend its reasoning in Rivera and more generally recognize Congress's "private attorney general" intent behind the Act, then the Court would have to replace its "changing the legal relationship" standard for qualifying civil rights plaintiffs for attorney's fees awards with a "vindication of rights" standard. Such a standard would require the overruling of Hewitt, Rhodes, and Farrar.

\section{A. Ignoring the "Private Attorney General" Doctrine Underlying the Act}

With devastating results, the Hewitt, Rhodes, and Farrar Courts all ignored the "private attorney general" theory inherent in the Act. To rectify its errors in this vein, the Court would have to recognize that private benefit, while sufficient, is not necessary to qualify a civil rights plaintiff as a "prevailing party."

The Court should discard Hewitt on two grounds. First, although the Hewitt defendants' qualified immunity had prevented Helms from obtaining any "relief on the merits," it had not kept Helms from earning a legal pronouncement that his civil rights had been violated. On the strength of this legal pronouncement alone, Helms was a "prevailing party." An award of attorney's fees coupled with this pronouncement would have informed potential rights violators that their violations would be prosecuted at their own expense. The fact that public benefit would have been engendered by consequent deterrence of rights violations should have qualified Helms as a "prevailing party." Second, the Court should overrule its holding that the district court need not consider whether or not Helms's suit had been a "catalyst" for the Pennsylvania Bureau of Corrections' revision concerning inmate disciplinary hearings. ${ }^{82}$ If Helms's suit was such a "catalyst," then regardless of the suit's outcome in court, Helms succeeded in generating the public benefit of reforming the Bureau's disciplinary hearings standards. Just as a plaintiff may "prevail" under section 1988 by obtaining a favorable out-of-court settlement that generates some private bene-

\footnotetext{
a plaintiff would have kept "those who violate the Nation's fundamental laws [from] proceed[ing] with impunity," S. REP. No. 1011, supra note 1, at 2, reprinted in 1976 U.S.C.C.A.N. at 5910, he would not have obtained the "relief on the merits" which the Court deems necessary to qualify a plaintiff as a "prevailing party."

81. Hewitt v. Helms, 482 U.S. 755,759 (1987).

82. Id. at $759,763$.
} 
fit for the plaintiff, a plaintiff "prevails" by generating a public benefit through a defendant's "voluntary" action. ${ }^{83}$ If Helms's suit had encouraged the change in policy, which change constituted a restoration of citizens' civil rights, the suit generated a public benefit quite sufficient to qualify Helms as a "prevailing party."

Rhodes should be discarded because the Court erred in basing its holding on its finding that no party to the action had benefitted from the suit brought by plaintiffs Reese and Stewart, incorrectly stressing the suit's not having been brought as a class action. ${ }^{84}$ Although the two plaintiffs, one dead and the other released from prison by the time their case was finally resolved, had not personally benefitted from the improved treatment of prisoners mandated by the district court, ${ }^{85}$ society received a benefit from the court's vindication of the plaintiffs' rights by virtue of the court's restraining the defendants from denying other prisoners' constitutional rights. The direct public benefit engendered by the court's holding should have been sufficient to qualify the plaintiffs as "prevailing parties."

The Court should discard Farrar under the first rationale mentioned above for discarding Hewitt. The judgment in Farrar that Farrar's civil rights had been violated, which gave rise to the nominal damages award, had constituted a vindication of Farrar's rights. As in Hewitt, such a vindication would have generated a public benefit if coupled with an award of attorney's fees, which would have resulted in the defendant having been prosecuted at his own expense. The deterrence of future abuse of citizens' rights should have qualified Farrar for an award of attorney's fees.

\section{B. Undervaluing the Vindication of Rights}

Consideration of Congress's intent in passing the Act leads to the conclusion that a civil rights plaintiff should be deemed to qualify for an award of attorney's fees whenever he vindicates his rights, ${ }^{86}$ rather than, as the Court currently holds, only when he succeeds in changing the legal relationship between the defendant and himself. Justice O'Connor seemed to recognize Congress's

\footnotetext{
83. See supra note 79.

84. Rhodes v. Stewart, 488 U.S. 1, 4 (1988).

85. See supra text accompanying notes 57,61 .

86. See supra subsection I(B)(2).
} 
intent in her Farrar concurrence, but she failed nonetheless to appreciate the richness of any vindication of rights coupled with an award of attorney's fees.

Justice O'Connor dismissed out-of-hand the idea that the Farrar litigation served any public purpose, asserting that

one searches these facts in vain for the public purpose this litigation might have served. The District Court speculated that the judgment, if accompanied by a large fee award, might deter future lawless conduct ... but did not identify the kind of lawless conduct that might be prevented. Nor is the conduct to be deterred apparent from the verdict, which even petitioners acknowledge is "regrettably obtuse."

Justice O'Conner placed great weight on the district court's failure to specify the particular public purpose the litigation inight have served or the particular future lawless conduct that might be deterred. Yet such oversight was likely due in great part to the Court's recent indications-i.e., Hewitt and Rhodes-that public benefit is to be of little concern in assessing a civil rights plaintiff's success.

In fact, after Justice O'Connor recognized that the Act was meant to be used as "a tool that ensures the vindication of important rights," 88 she should have easily concluded that the litigation provided a valuable public purpose-the vindication of Farrar's civil rights and the concomitant deterrence of similar rights violations in the future. Vindication of a plaintiff's civil rights, coupled with an award of attorney's fees reasonably incurred in the attainment of the vindication, deters future rights violations through the recognition of the validity of the claimed right and the declaration that rights violators will be prosecuted at their own expense. ${ }^{89}$ Vindication of a plaintiff's civil rights provides the important public benefit of deterring future rights violations.

Justice O'Connor was not willing to analyze deterrence under the rubric provided by Congress; nor was she willing to remand to the district court so that the trial judge would have that opportunity. Instead, she pronounced that because the finding that one of Farrar's civil rights had been violated was "regrettably obtuse," there is no public benefit to be gained from the obtaining of such

87. Farrar v. Hobby, 113 S. Ct. $566,578-79$ (1992) (O'Connor, J., concurring).

88. Id. at 578.

89. See supra notes $23-24$ and accompanying text. 
a judgment. By denying Farrar an attorney's fees award, Justice O'Connor stated, effectively, that Farrar's is not the kind of suit that is in the public's interest to litigate-that society would be just as well off if such a suit, with such an outcome, were not litigated.

By denying the value of the jury's declaration that Farrar had been the subject of malicious prosecution, Justice O'Connor missed the opportunity to deter future malicious prosecutions-and demonstrated her unwillingness to recognize the consequences of Congress's "private attorney general" intent in passing the Civil Rights Attorney's Fees Act of 1976. To prevent such discouragement of appropriate litigation, the Court should distance itself from Justice O'Connor's concurrence; a vindication of rights should be recognized as qualifying a civil rights plaintiff for an award of attorney's fees incurred in the attainment of such a vindication.

\section{Ramifications of Recognizing the "Private Attorney General" and "Vindication of Rights" Precepts}

Consider again the hypothetical featured in the Introduction. Joe's rights were vindicated: Upon the entry of judgment in his civil rights suit, he obtained a judicial pronouncement that his civil rights had been violated. Yet under the Supreme Court's current interpretation of the Act's "prevailing party" language, the trial court would not be able to award Joe attorney's fees. This result would not be conducive to effecting Congress's aspiration of eradicating civil rights abuse. Attorneys would become increasingly hesitant to take on clients like Joe. Despite these clients' legitimate claims of having suffered violations of their civil rights, the likelihood that either the client would not be able to pay or that the court would not award attorney's fees would result in these clients' inability to obtain legal representation in these important cases. To accord with Congress's intent in passing the Civil Rights Attorney's Fees Act of 1976, the Court must re-construe the "prevailing party" language of the Act so that civil rights plaintiffs with valid claims are encouraged to aid in the eradication of civil rights abuse.

The legislative history of the Civil Rights Attorney's Fees Act of 1976 clearly indicates that civil rights plaintiffs are "private attorneys general"; as such, they "prevail" whenever they generate a public benefit. Furthermore, the legislative history specifically pro- 
vides that a "vindication of rights" constitutes such a public benefit. Adhering to these precepts expressed in the legislative history would require the Supreme Court to abandon its requirement that a plaintiff receive "some relief on the merits" before he "prevails." Instead, the Court would have to recognize that a plaintiff-who either has obtained a legal pronouncement that his civil rights were violated or has encouraged a defendant to change "voluntarily" his behavior to society's advantage-has "prevailed" and thus is eligible for an award of the legal fees generated in obtaining the pronouncement or encouraging the behavioral change. Such a pronouncement certainly occurs whenever a plaintiff receives some relief on the merits; but it also occurs in many cases, such as Hewitt, Rhodes, and Farrar, when there is significant public, albeit no recognizable private, benefit.

\section{CONCLUSION}

To accord with legislative intent, the Court must further explore the "private attorney general" theory underlying the Act which it recognized in Rivera. Contrary to Justice Scalia's assertion in Hewitt, a plaintiff qualifies as a "prevailing party" long before, and regardless of whether, he "receives some relief on the merits of his claim." Rather, a civil rights plaintiff is a "private attorney general" who becomes eligible for an award of attorney's fees under section 1988 as soon as he "vindicates" his rights. Such a plaintiff obtains such a "vindication of rights" upon either earning a legal pronouncement that his rights have been violated or causmg the defendant to "voluntarily" change his behavior to the advantage of either the plaintiff himself or society as a whole. Seeking to encourage the enforcement of everyone's civil rights, Congress intended to compensate not just those plaintiffs who succeed in ensuring the maintenance of their own rights, but also those who succeed in ensuring the maintenance of the rights of all. 